\title{
W mocy tekstu
}

\section{In the lap of the text}

\author{
Jan Wawrzyniak \\ UNIWERSYTET IM. ADAMA MICKIEWICZA \\ AL. NiePOdLEGŁoŚCI 4, 61-874 POZNAŃ \\ jawa@amu.edu.pl
}

\begin{abstract}
The text hereby presented is written in the form of an essay and, at the same time, it promotes this form - as a particular, cognitively efficient model of philosophical as well scientific investigations. It contains analytical deliberations on the sophisticated relations between a philosophical text and its nominal author who is governed by the internal logic of the narration and who 'vanishes' while writing. There are also the issues of an author's professional methodological responsibility for the writing as well as the creative-interpretational function of addressees taken into account. Some necessary references to the philosophy of science as well as the philosophy of language are present in the essay, too. And within this scope, an explanatory narration is identified with a parameterization of the world being explained or described; and the so-called description always remains preferential. A significant part of the article contains some remarks about the Polish education system in the context of both tradition and perspectives of the development of European culture. What is particularly stressed is the role of the humanities in the process of educating young people who should be responsible enough to take care of the axio-variety of human culture in the future. Therefore, the conceptions of the so-called area ethics and culture enrichment ethics are emphasized as well.
\end{abstract}

Pamięci Anny Zeidler-Janiszewskiej

Praktyka pisania ma na celu wyeliminowanie obecności pisarza

É. Gilson, Lingwistyka a filozofia

Poniższe przemyślenia oparte są na doświadczeniu pisania pandyscyplinarnych prac filozoficznych, a w szczególności będą się odwoływały do procesu powstawania jednej z nich: Etyka eutanazji. Studium 
filozoficzno-aksjolingwistyczne (2015), nawiązując do niektórych jej sformułowań, a głównymi motywami tematycznym będą zarówno relacja lącząca piszącego z tekstem, w tym swoiste doświadczanie 'śmierci/zanikania autora' podczas pisania, jak i kognitywny charakter narracji interpretacyjnej. Zawierają także bardziej ogólne refleksje o edukacji humanistycznej. Chciałbym je skierować przede wszystkim do doktorantów i młodych duchem twórczym naukowców, czyli zmagających się z narracją poszukiwaczy prawdy, która pozostaje aproksymacyjna, zależna od kontekstu przemian kulturowych, w tym osiągnięć cywilizacyjnych i technologicznych. Prawda naukowa jest zarówno procesualna (tu: perspektywa falsyfikacjonizmu K.R. Poppera) jak i uzależniona od teoretycznych konstrukcji, czyli intelektualnych gier, $w$ ramach których jest formułowana (tu: perspektywa tzw. drugiej filozofii L. Wittgensteina). Nauka - co wynika z jej ufundowania stricte filozoficznego - to odkrywanie heurystycznych inspiracji poznawczych, a nie przymus konkludowania. W praktyce badawczej konieczne jest uświadomienie sobie polimorficzności prawdy oraz jej interpretacyjnego, czyli eksplanacyjno-preferencyjnego charakteru, ujawniającego zarazem adeptom nauki ograniczenia ich własnych mocy intelektualnych. Aczkolwiek nie wolno rezygnować z racjonalnej - a więc zakładającej dystans do owych mocy - ambicji stworzenia Wielkiej Teorii, to ważna jest mentalna wolność od autoprzymusu bycia 'jedynym wtajemniczonym'. Trzeba natomiast odnaleźć własną niszę merytoryczną, w której wypadało będzie być najwyższej miary specjalistą, czyli nigdy sądzić, że wie się wszystko do końca. Profesjonalista jest zawsze sceptykiem. Postplatoński ideał prawdy bezpośredniej - niezapośredniczonej przez zmysły, język, teorie, preferencje aksjologiczne, trendy kulturowe etc zawsze pozostanie ściganym marzeniem. Stąd nauka to najciekawszy sposób na życie: nie pozwalająca zasnąć w ułudzie prawdy ostatecznej, nieskończona podróż przez niezmierzone bogactwo kreatywnych zdziwień.

Przede wszystkim należy: (i) akceptować, iż nasza narracja pozostanie jednym z wielu ujęć danego zagadnienia, funkcjonujących $\mathrm{w}$ sferze kultury intelektualnej; a także (ii) uświadomić sobie bezsens pisania 'na silę'. Fałsz pisania, a w konsekwencji poznawczą jego jałowość, poznaje się po niechęci do tekstu, traktowanego przez piszącego jako zewnętrzny przymus ze standardową sankcją typu deadline. Aby zacząć pisać potrzebna jest inspiracja w postaci ośrodkowego - intelektualnie 'toksycznego' i osobiście przeżywanego - zagadnienia, wokół którego narracja będzie uorganizowana; kardynalne jest więc uruchomienie merytorycznego pomysłu własnego. Świetnym zaczynem bywa problem zrodzony ze zdziwienia nad pozornie bezdyskusyjnym banałem, obecnym w świadomości potocznej. W przypadku wspomnianej pracy (Etyka eutanazji) okazał się nim sposób funkcjonowania słowa „eutanazja” w uzusie. Intrygujący bo świadczący o paradoksalnym jego społecznym rozumieniu. Jak to się bowiem stało, że termin ten - będąc pozornym oksymoronem: wszak skojarzenie śmierci (thánatos) z egzystencjalnym doświadczeniem, które miałoby być pozytywne (eu) kłóci się z instynktowną ludzką intuicją i przekonaniami - stał się dziś zaprzeczeniem 
oryginalnego greckiego jego rozumienia, w tym literalnej treści? A i samo antyczne skojarzenie śmierci z prefiksem eu jest wielce frapujące. Jak doszło do współczesnej multipolaryzacji w pojmowaniu „eutanazji”, zwielokrotnienia $\mathrm{i}$ niekoherencji odniesień tego terminu oraz jego aksjosemantycznej degeneracji? Zadania badawcze dotyczyły wyjaśnienia tego fenomenu, a w konsekwencji angażowały studia nad historycznymi przemianami zakresu konotacyjnego , nakładaniem się znaczeń, funkcjonowaniem znaczeń równoległych o przeciwstawnych wektorach aksjologicznych, gromadzeniem się eufemizów, kakofemizmów, terminologii synonimicznej i bliskoznacznej. Materiałem podjętych badań była więc praktyka językowa.

Przystępując do pracy należy dysponować zestawem odniesień badawczych, czyli konceptualnie ujętych aspektów zagadnienia głównego, które ma być analizowane. Odniesienia owe wchodzą w skład repertuaru pomysłów interpretacyjnych, generując zbiór pytań wiodących, który należy jasno sformułować we wstępnej partii tekstu. Innymi słowy: trzeba dysponować jakąśs - na poziomie rozstrzygnięć podstawowych - teorią jako wykładnią interpretacji. W przypadku przywołanej tu rozprawy była to filozoficzno-lingwistyczna teoria aksjojęzykowego obrazu świata (AJOS-u), w świetle której społecznie funkcjonujące sposoby rozprawiania o zagadnieniu eutanazji, kreują jego normatywne sproblematyzowanie. Obrazy owe są rezultatem preferencyjnej i kreatywnej parametryzacji przedmiotu poznawanego w samych procedurach epistemicznych. Świat, w którym żyjemy jest taki, jakim jest językowo kodowany i jest to argument by rozważania o moralnym statusie działania określanego jako „eutanazja” poprzedzić starannym ustaleniem konotacyjnego spektrum tego terminu. Tu ujawnia się fundamentalna rola etapu kwerendy, aby nie powielać zagadnień już dawno rzetelnie opracowanych oraz wyselekcjonować referencje poznawczo heurystyczne. Pracować należy przede wszystkim na oryginalnych tekstach źródłowych i darzyć ograniczonym zaufaniem informacje podawane nawet przez uznanych autorów, a to z uwagi na ich możliwe pomyłki lub powielanie spetryfikowanych błędnych sformułowań czy przekonań. Przy kwerendzie wykrywa się też prace wtórne oraz plagiaty. Zważmy, iż Tekst pisze/dzieje się przez pokolenia wielu autorów, czyli jego mediów, a każda oryginalna praca pozostaje ogniwem dia- i synchronicznie rozumianej struktury Wiedzy. W ciągu dziedzictwa kompetencji poznawczej (w danym zakresie tematycznym), kreatywność interpretacyjna kolejnego medium wzbogaca ową strukturę.

Pozwólmy sobie w tym miejscu na kilka akapitów niezbędnej dygresji z zakresu filozofii nauki i języka. Jej kontekstem niech będzie ewolucja epistemologicznych poglądów na relację: podmiot $\leftrightarrow$ przedmiot poznania. Przeszły one historyczną przemianę od postawy receptywizmu poznawczego (Arystoteles) przez stopniową aktywizację upodmiotowienia uzyskiwanego 
obrazu świata (J. Locke, G. Berkeley, D. Hume), po całkowite wchłonięcie świata zewnętrznego przez podmiot, który tenże świat apriorycznie parametryzuje (I. Kant), a nawet po pragmalingwistyczne kreowanie znaczeń (późny L. Wittgenstein). W rezultacie obiektywność stała się życzeniowa, jako niezbędny dla podmiotu poznającego stan świata, pozostając jako taka postulatem teoretycznym. A ponieważ jest ona kategorią epistemicznie (tu: $\mathrm{z}$ perspektywy realizmu pojęciowego) nierozstrzygalną, wszak jaki jest noumenalny świat poza jego teoretycznym obrazem nie jesteśmy w stanie wiedzieć, w poznaniu typu naukowego przyjęto ściśle określoną konwencję metodologiczną zwaną intersubiektywizmem terminologicznym i weryfikacyjnym (resp. falsyfikacyjnym). W konsekwencji: złudzenie wolności od wartościowania w procedurze teoretycznego wyjaśniania świata przestało istnieć, ujawniając swą metaaksjologiczność.

Parametry świata są kreowane (tzn. desygnowane, a nie denotowane) samym procesem poznawczym prowadzonym metodą naukową, kodowanym w języku i konstrukcjach teoretycznych, a fakty naukowe mają charakter konceptualny. Co więcej, pozostają zarazem preferencyjne, albowiem urok poznania naukowego polega na jego nomologiczności: nauka proponuje aksjoobraz bezpiecznego, bo regularnego i przewidywalnego, świata w którym chcemy żyć. I w tym znaczeniu ma ona charakter religijny (w sensie zaproponowanym przez L. Kołakowskiego w Obecności mitu; tj. przy rozumieniu religijności jako dyspozycji duchowej, a nie kategorii socjologicznej, odniesionej do tzw. sekularyzacji), czyli proponuje odniesienia sensownie/racjonalnie tłumaczące jednostkowe fakty, w tym ludzkie egzystencje, odpowiadając tym samym na wrodzoną człowiekowi potrzebę takich odniesień. Przy czym są to referencje transcendentalne (kulturowe), a nie transcendentne (supranaturalne). Nauka stwarzając nadzieję, zarazem pozbawia złudzeń. A złudzeniem pozostaje (neo)pozytywistyczny kult „czystego faktu” oraz nauki wolnej od wartościowania i założeń aksjometafizycznych, kult kwantytatywnej prawdy absolutnej i wiedzy ostatecznej. Tego typu wizja nauki pozostaje w istocie apoznawcza, bo biernie-receptywna, nieprocesualna, chcąca uniknąć odpowiedzialności intelektualnej za teoretyczną interpretację badanego świata, w tym za interpretację danych doświadczenia jako „czystych faktów” właśnie, która to kategoria może nawet stanowić maskę okrucieństwa (np. w biologii eksperymentalnej).

Poznanie naukowe, będące kulturowo uwarunkowanym typem praktyki społecznej, odbywa się w ramach spektrum językowych możliwości kodowania wiedzy rezultatowej. Tam, gdzie konieczna jest werbalizacja i konceptualizacja w procesie poznawczym, edukacyjnym i komunikacyjnym, język wyznacza granice akwizycji i przekazu wiedzy, czyli granice znanego świata, który poza ową konceptualizacyjną interpretacją, porządkującą doświadczenie zmysłowe, pozostaje niezróżnicowaniem i nieokreślonością. Język kategoryzuje świat zgodnie z preferencjami poznawczymi człowieka, działając w ramach możliwości pojęciotwórczych umysłu ludzkiego jako 
tworu ewolucyjnego, odzwierciedlającego strukturę (nomologiczne uporządkowanie) świata pozapodmiotowego. Ten izomorfizm jest zrozumiały np. na gruncie metafizyki abstrakcyjnego panteizmu, znoszącego dualizm wiedzy (stanu umysłu) i przedmiotu wiedzy (stanu świata). Obiekt poznania wyłania się $\mathrm{z}$ samej narracji badawczej (konceptualizacji danych poznawczych), która go parametryzuje jakościowo (atrybutywnie) i formalnie. Eksplanacyjna narracja prowadzi nominalnego autora, który konsekwentnie wnioskując, konsekwentnie musi konkludować. To sam tekst otwiera nowe wątki, aspekty, wątpliwości i staje się samosterownym wehikułem piszącego w podróży przez odkrycia problemowe. Tekst zmusza do szukania i zastosowania nowych językowych środków wyrazu, w rezultacie czego niepostrzeżenie, ku zaskoczeniu nominalnego autora, powstaje nowy obraz świata, wygenerowany samą logiką konsekwentnej narracji wnioskującej. Odkrycie naukowe, np. teoria tłumacząca jakąś empirycznie daną zagadkę, ma w sobie wiele z intelektualnego artyzmu, awangardowej inwencji wyobrażeniowej i intuicyjnej, wymaga też śmiałości kulturowej w przełamywaniu schematów koncepcyjnych. A jeśli język nauki nie wystarcza, to aby dotrzeć do pokładów ludzkich doświadczeń i zaproponować nowe rozumienie czegokolwiek, sięgamy do poezji, muzyki czy nomenklatury i frazeologii innego typu oraz szukamy możliwości słowotwórczych. Tekst (słowa), muzyka (nuty), światło (kolory), taniec (gesty), czyli języki w całym ich zniuansowaniu - także poprzez zaniechanie, milczenie, ciszę czy ciemność - kierują medium zwanym autorem, by stawać się filozofią, nauką, literaturą, symfonią, malarstwem, religią, ideologią etc. Ów nominalny autor pozwala im na aktualizację interpretacyjnego potencjału i zaistnienie w bezpośrednio percypowalnej dla ludzkich podmiotów formie zwanej kulturą.

Wypada zgodzić się z M. Heideggerem, że język/mowa jest swoistym domostwem Homo sapiens jako kulturowego bytu. Interpersonalna $\mathrm{i}$ interpokoleniowa (historyczna transmisja wiedzy nabytej) komunikacja werbalna pozostaje szczególną (choć rzecz jasna nie jedyną) forma ekspresji ludzkiej egzystencji. Rzeczywistością świadomości społecznej rządzą interpretacje, czyli preferencyjne tłumaczenia świata generowane makrokulturowymi, transpokoleniowymi przemianami warunków życia danej zbiorowości. Dynamika tych przemian zmienia ludzkie wektory i hierarchie wartościowań. Społeczeństwa reagują światopoglądowymi przewartościowaniami - mogącymi przybrać wymiar zmian legislacyjnych na skutki swoich własnych dokonań. Każda opcja światopoglądowa ma w uniwersum kultury swoje miejsce, wraz ze złudzeniami o własnej wyższości i prawdziwościowej wyłączności. Afirmację teoretyczno-interpretacyjnego pluralizmu wiedzy naukowej, a w konsekwencji stanu metaprawdy o istnieniu wielu epistemicznie równowartych obrazów świata wyraża współczesna koncepcja area ethics, czyli holistycznej etyki postępowania badawczego i edukacyjnego w kwalifikowanych obszarach problemowych (areas), ze szczególnym uwzględnieniem humanistyki, której produkty teoretyczne stanowią autoobrazy ludzkiego Lebensweltu, zwrotnie oddziałujące na społecznego odbiorcę. Opcja ta postuluje - w praktyce badawczej, 
dydaktycznej oraz dyskursie publicznym - intelektualną otwartość, dialogowość oraz heurystyczne tworzenie szerokiego spektrum teoretycznych ujęć problemów naukowych. Tym samym area ethics realizuje wartość intelektualnej tolerancji w formie egalitarnej prezentacji (np. dydaktycznej) spektrum różnorodności - metodologicznie prawidłowo uzasadnionych poglądów na dany temat.

Etyka ta odchodzi od linearno-korespondencyjnego modelu rozwoju nauki, na rzecz symultanizmu i swoistego kubizmu teorii wyjaśniających świat. Sugeruje, iż na danym etapie rozwoju nauki, jako kulturowo determinowanej praktyki społecznej, funkcjonuje wiele równowartych eksplanacyjnie (interpretacyjnie) teorii funkcjonowania świata (resp. jego elementów), ale tylko niektóre $\mathrm{z}$ nich się rozpowszechniają uzyskując instytucjonalno-akademickie wsparcie. Dzieje się tak za sprawą makrotrendów 'ducha epoki', czynników pozostających w kontekście okołonaukowym (np. moralnych, ekonomicznych, artystycznych, politycznych, religijnych itp.), czy nawet intelektualnych mód (np. postmodernizm). Wobec teorii naukowych działają preferencje kulturowe, czego rezultatem jest akademicka obecność tylko pewnych modeli eksplanacyjnych, nielepszych od pominiętych konkurentów. Area ethics preferuje kumulacyjno-selektywną wizję (swoistą i dyskusyjną syntezę pozytywizmu z hipotetyzmem/falsyfikacjonizmem K.R. Poppera) rozwoju wiedzy, dokonującego się poprzez wzbogacanie puli możliwych rozstrzygnięć stricte scjentycznych i ich kulturowego doboru. Postęp polegałby na tworzeniu struktury komplementarnych, interdyscyplinarnych perspektyw i obrazów świata, wyjaśniających przynajmniej tyle samo choć inaczej i akcentujących odmienne atrybuty rzeczywistości badanej. Wiedza, będąc zrelatywizowana do transcendentalnych (intersubiektywnych) obserwatorów reprezentujących dane areas (dyscypliny naukowe, obszary badawcze), rozgałęzia się inter- i pandyscyplinarnie. Historycznie skumulowany pozostaje też metodologiczny kanon naukowości postępowania badawczego: intersubiektywna komunikowalność i sprawdzalność, niebanalność informacyjnej zawartości, ścisła ogólność, czyli moc eksplanacyjna, prostota logiczna (redukcja ilości aksjomatów), koherencja i heurystyczny potencjał teorii. Inaczej mówiąc: stała jest idea wiedzy prawdziwej w sensie klasycznym (wraz z wprowadzoną przez A. Tarskiego językową relatywizacją relacji prawdziwości), zmieniają się zaś metakryteria weryfikacji, czyli uznawania tej prawdziwości. Zarówno area ethics jak i reprezentowany wymienioną na wstępie pracą filozoficzno-metaetyczny neonaturalizm (por. też: Teoretyczne podstawy neonaturalistycznej bioetyki środowiskowej) zakorzenione $\mathrm{w}$ procesualistyczno-ewentystycznej metafizyce - afirmują wielość rozwiązań, interpretacji, światopoglądów, przekonań normatywnych etc., w imię trwania Wielkiej Puli Różnorodności Bytu, w tym aksjosfery kultury.

W kulturze europejskiej klasyczne ideały racjonalności, wolności, szczęścia, piękna czy dobra są realizowane przez poszczególne epoki w 
swoisty dla nich sposób, a narosłe przez wieki kanony naukowości pozostają umowami społecznymi - ściślej: konwencjami filozoficznymi obowiązującymi na kolejnych etapach rozwoju wiedzy ludzkiej. Paradygmaty, a stąd i teorie naukowe wyrażają historycznie i kulturowo uwarunkowane intelektualne, preferencyjne (co wynika ze społecznie funkcjonujących hierarchii ważności) projekcje sposobów językowego ujmowania zjawisk dostępnych empirycznemu poznaniu. Aby zrozumieć proponowane przez daną teorię tłumaczenie świata, trzeba znać jej filozoficzne (metafizyczne, epistemologiczne, aksjologiczne, logiczne etc.) i światopoglądowoideologiczne uwarunkowania oraz stan wiedzy naukowej (wraz ze stanem metaświadomości filozofii nauki i odpowiadających jej metodologicznych kanonów naukowości) w czasie i miejscu powstania owej teorii; trzeba też znać aparaturę pojęciową jaką posługuje się nauka (tu: dziedzina kultury symbolicznej) komunikując swoje diagnozy rzeczywistości w danych okresach. Ponieważ prawda naukowa jest ufundowana na wartościowaniach ukrytych w kulturowym tle wymogów stawianych praktyce naukowej i stąd zrelatywizowana do historycznie danego stanu tej praktyki, postulatem area ethics jest badanie normatywnych fundamentów teorii (modeli eksplanacyjno-interpretacyjnych) naukowych i intelektualnych stylów uprawiania nauki: motywów wyboru priorytetów badawczych, doboru aksjomatów wyjściowych, wprowadzania danej kategoryzacji i terminologii, sposobów stawiania pytań, formułowania hipotez i konceptualizacji definicyjnych; istotne są tu zakładane wizje aksjometafizyczne, antropologiczno- i socjofilozoficzne (np. koncepcje natury ludzkiej, ideału społecznego, czy dialektyki wolności i predestynacji).

Teorie naukowe implicite opierają swe aksjomaty na przekonaniach metafizycznych i metanaukowych o charakterze aksjologicznym, a każda dąży do realizacji wartości zwanej prawdą. Czytając teksty źródłowe (szerzej: literaturę przedmiotu) do podjętych badań trzeba być świadomym owych milczących założeń i przyjętych w nich standardów naukowości oraz wartości jakie przyświecały rozpowszechnianiu się danych trendów intelektualnych. To wielkie, epokowe przemiany kulturowe, w szczególności w sferze aksjometafizycznej i filozoficzno-antropologicznej generują nowe zakresy konotacyjne kategorii pojęciowych, a nowy stan świadomości moralnej (sfera ius) wpływa z kolei na decyzje cywilizacyjne (np. w sferze lex). Ideały naukowości, wyrażające tęsknotę za uniformizmem metody poznawczej wraz z ludzkim dążeniem do ostatecznej prawdy o świecie stanowią postoświeceniową mutację religijności, a więc naturalnej ludzkiej potrzeby spójnego i nomologicznego obrazu świata oraz zdefiniowanego miejsca człowieka w nim. Jednakże nauka działając w realnej poliaksjologicznej i procesualnej rzeczywistości, którą współtworzy, musi afirmować wielość tak w perspektywie synchronicznej (np. eko-etnologicznej), jak i diachronicznej/historycznej - prawd o świecie jako kulturowe status quo, traktując także ją samą jako zagadnienie badawcze. Neonaturalizm i area ethics reprezentują tę racjonalistyczno-tolerancyjną tradycję śródziemnomorskiego kręgu kulturowego. Podsumowując: paradygmaty 
naukowe, teorie i hipotezy, a także opcje światopoglądowe obrazują istotne przemiany aksjologiczne społeczeństw. Także ewolucja znaczeń „dobra”, "wolności”, „prawdy”, „piękna”, „sprawiedliwości”, czy innych aksjoleksemów, pozostaje - zachowanym w języku - fragmentem kroniki kultury europejskiej. Samo poznawanie jest twórczością interpretacyjną, współkomponującą bogactwo kultury. Poprzez aksjologiczny komponent poznania język stwarza przestrzeń znaczeń, a kulturę buduje spotykanie się różnych poznawczych desygnacji świata, czyli hierarchii ważności w życiu człowieka. Spektrum sproblematyzowania danej kwestii badawczej stwarzane jest sposobami jej narracji, które zapełniają świadomość społeczną konkurującymi AJOS-ami, a w konsekwencji generują semiotyczny zakres jej identyfikacji.

Prawda naukowa nie jest partyjna, konfesyjna, ani sama w sobie dialektyczna, czy wariabilna, lecz spełniać musi ściśle określone, metodologiczno-kryterialne wymogi. Jednakże nauka nie działa dychotomicznie (jak być może chciałby Arystoteles), lecz dopuszcza spektrum równoległych, alternatywnych prawd, czyli wyjaśnień świata, sformułowanych z osobna na gruncie różnych teorii; wyjaśnianie jest zarazem wyborem samego sposobu wyjaśniania, tyleż intelektualnym, co kulturowo zakorzenionym wyborem stałych (aksjomatycznych) odniesień nomologicznych w praktyce poznawczej. A interpretacja stanowi niezbywalny, immanentny komponent teorii wyjaśniającej dane obserwacyjne. Musi być spójna wewnętrznie, a zarazem niesprzeczna z owymi danymi, podlegającymi oglądowi naukowemu zgodnie $\mathrm{z}$ zasadą nieoznaczoności. I to ona zamienia Boga na Wielki Wybuch, gdyż teoria jako taka pozostaje wytworem makroprocesów w aksjosferze kultury. Interpretowanie naukowe to tworzenie heurystycznego spektrum równowartych poznawczo wyjaśnień danego przedmiotu badań, czyli równoległych oraz komplementarnych odpowiedzi na pytania: dlaczego? (kontekst kauzalny); po co? (kontekst teleologiczny); w jakich okolicznościach? (kontekst sytuacyjny); w ramach jakich prawidłowości? (kontekst nomologiczny) etc. Interpretacje to różne sposoby intelektualnego przetwarzania informacji wspólnych dla wszystkich podmiotów poznania; tworzą one kulturowy metastan pluralizmu teorii wyjaśniających świat. Zarazem epistemiczny kreacjonizm nauki powoduje, iż bada ona swe własne wytwory teoretyczne, czyli pozostaje autoreferencyjna. Prawda naukowa polega na zgodności twierdzeń o świecie z teorią tegoż świata. Dopiero jeśli nowe dane empiryczne nie dadzą się koherentnie zinterpretować na gruncie danej teorii jako potwierdzające ją, wtedy odrzucamy teorię, gdyż to nie owe dane falsyfikują teorię, lecz jej eksplanacyjno-interpretacyjna spójność stanowi kryterium tejże weryfikacji/falsyfikacji. O wyczerpywaniu się mocy eksplanacyjnej danej teorii świadczy inna teoria, niekoniecznie następna, ale na przykład równoległa, pozwalająca wytłumaczyć, czyli zinterpretować kłopotliwe dane empiryczne. 
Powróćmy do głównego wątku rozważań. Gdy zakres pytań badawczych i ich potencjalnych kontekstów interpretacyjnych stanie się klarowny, pojawia się kwestia zastosowania formy narracji, odpowiedniej do eksploracyjnego poprowadzenia tak piszącego, jak i czytelnika przez analizowane zagadnienie. Filozofowie akademiccy miewają problem z metarefleksją nad wyborem poznawczo funkcjonalnej formy prowadzenia dociekań i wywodów w danym obszarze problemowym. W humanistyce destrukcyjnie działa rutyna wykładowa i schematy opracowywania danych zaczerpnięte $\mathrm{z}$ nauk empirycznych. Zapominamy, iż pozytywistyczny miraż nauki wolnej od wartościowania sam w sobie jest normatywny, a tzw. fakty naukowe pozostają teoretycznymi aksjo-konceptualizacjami (tzn. są preferencyjne). Poszukiwanie modelu - swoistej logiki konstruowania - struktury narracji odbywa się w całym ogrodzie nauk i sztuk, a w rozprawie filozoficznej - z samej istoty tego typu dociekań - szczególnie uzasadnione są eksperymenty narracyjne, pozwalające wydobyć z analizowanych zagadnień i pojęć bogate konotacyjne spektrum interpretacyjnych możliwości. W przykładowo wymienionej na wstępie pozycji zastosowano wprowadzoną do filozofii przez Michela de Montaigne dyskursywną formę eseju.

Esej jest formą przyjazną nieuchronnej preferencyjności (normatywności) narracji. Wszak czyste deskrypcje nie istnieją, pozostając uznanymi za prawdziwe bądź fałszywe - według umownych i językowo zrelatywizowanych konwencji (!) - odniesieniami do rzeczywistości pozajęzykowej, a zarazem metaaksjologicznym ideałem. Tak zwana opisowość pozostaje desygnacją świata poznawanego, konstruując go jako taki czy inny, jakoby wiernie odtworzony językowo; na takiej samej zasadzie desygnacją jest tzw. literalność odczytu tekstów kanonicznych. Jaki jest noumenalny świat nieprzefiltrowany przez zmysły i aparaturę badawczą, preferencje teoretyczne, systemy wartości, kulturowe makroparadygmaty intelektualnoświatopoglądowe oraz językowe kodowanie i przekazywanie wiedzy o tym świecie nie dowiemy się nigdy. Powtórzmy: nauka bada uniwersa przez siebie teoretycznie desygnowane, a dane empiryczne weryfikują bądź falsyfikują teorie naukowe przez interpretacyjne odwołanie się do tychże teorii. To kardynalna epistemiczna 'tautologia' (typu: $\mathrm{p} \rightarrow \mathrm{p}$ ): poznawanie świata pozostaje zarazem jego konstruowaniem. Tak zwana obiektywność (czy absolutność) to desygnacyjny korelat/implikator wiedzy (założeń lub konkluzji), w szczególności przekonań aksjometafizycznych. Prawda pozostaje - w całym spektrum kulturowo-kryterialnych jej konwencji wartością, a więc kategorią życzeniową. Esej preferuje interdyscyplinarność i hermeneutyczną alegorezę w podejściu do tekstów źródłowych, pozwala na wątpliwości i pytania otwarte oraz na sylwiczny moduł narracji. Multiaspektowa dyskursywność eseju uwypukla, iż możliwych spójnych interpretacji świata, współtworzących bogactwo aksjosfery kulturowej jest wiele i to model narracyjny okazuje się modelem świata i ludzkiego życia. Ponieważ sama narracja rodzi kolejne zagadnienia, a wątki problemowe powracają wzbogacone o nowe kontekstowe współbrzmienia, jej tok może stać się np. swoistym inkluzywnie narastającym ‘Bolerem'. 
A jak praktycznie zacząć pisanie, zabrać się doń? Ano, po prostu zacząć notować co w duszy gra, nie żądając od siebie od razu kompletnej linearności narracji, ona bowiem się wyklaruje wraz $\mathrm{z}$ rozwijaniem się Tekstu. W początkach opracowywania tematu praktycznym wydaje się kubizm literacki: notowanie rozwiniętych myśli, pomysłów, aspektów, kontekstów, które podsuwa sam Tekst. Zgrabnie jest wyjść od pytania „dlaczego zamierzam pisać na dany temat?” Następnie wypada poddać się wewnętrznej logice narracji i następujących w niej wniosków. Za zakrętami kolejnych konkluzji pojawiają się nowe horyzonty badawcze i heurystyczne zaskoczenia. Tekst poprowadzi ku poziomowi funkcjonalnej abstrakcyjności owych konkluzji, uspójniającej poszczególne wątki. Na początku pisania nie wiadomo jakie cenne rezultaty badawcze przyniesie procedura kumulatywnego zbiegania się linii subtematycznych i konsekutywnego uznawania wyników wnioskowań. Finalne podsumowania powinny zaszokować piszącego, obalić jego wstępne przekonania. Relacja miedzy nominalnym autorem a Tekstem to doświadczenie odkrywania. Tekst-eksplorator prowadzi i twórczo inspiruje piszącego, odczytywanego z kolei interpretacyjnie, czyli kreatywnie przez odbiorców. To ostatecznie Tekst i czytelnicy informują pisarza o czym pisał (tu: znamienne motto do Historii Filozofii W. Tatarkiewicza, zaczerpnięte z pism I. Kanta). A rozumienie Tekstu przez odbiorców-interpretatorów, do których on po opublikowaniu należy, uwarunkowane jest kulturowym i przekonaniowym kontekstem ich wykształcenia i egzystencji. Zaś w perspektywie aksjometafizycznej to Logos-Słowo/Tekst, inaczej: Wielki Algorytm Bycia (Informacja Metafizyczna), przekazuje się memowo przez kreatywnych filozofów, naukowców, artystów, religijnych mistyków itp., czyli bezpośrednie media interpretacyjno-preferencyjnych wyjaśnień świata (tu: AJOS-ów).

Zarazem nie trzeba się spieszyć z zakończeniem pisania. Tak zwany deadline (np. przy realizacji grantu) stymuluje tylko do momentu, gdy staje się przygniatający, zmuszający do skrótów, uproszczeń, opuszczeń ergo autorskiego (mediacyjnego) niespełnienia. Żaden projekt badawczy jest w stanie uwzględnić wszystkie aspekty problemowe i precyzyjnie wyznaczyć czasokresy realizacji poszczególnych zadań cząstkowych. Zawsze na bieżąco pojawiają się niuanse oraz niespodziewane wątki do rozpatrzenia wraz z kolejnymi lekturami i koniecznością weryfikacji ich wiarygodności. Gdy pojawia się problem wynikający z logiki narracji, zarówno konkretny, jak i polegający na tym że 'czujemy', że czegoś brak (niczym składnika w potrawie) by spuentować dywagacje, trzeba pozwolić podświadomie popracować umysłowi, a werbalizacja intelektualnego niepokoju i uspokojenia rozwiązaniem zjawi się sama. To Tekst decyduje o dzianiu się narracji, jej kierunkach i niespodziewanych konkluzjach za meandrami fraz. 'Śmierć autora', rozumiana jako jego 'zanikanie' w trakcie pisania, ma uczynić tekst wyłącznie problemowym, czyli czystą narracją merytoryczną, eliminującą stronnicze ingerowanie ze strony piszącego medium, np. w formie unikania $\mathrm{z}$ jego strony wniosków lub odwołań zgodnych z logiką narracji, lecz niewygodnych dlań aksjologicznie. Tekst prowadzi ku najbardziej nawet 
drażniącym go rejonom intelektualnym, stanowiąc korekcyjne zwierciadło, a nawet rodzaj 'wiwisekcji' jego dotychczasowych poglądów. I właśnie dyskursywność eseju pozwala piszącemu na osiągnięcie poziomu transcendentalnej intersubiektywności rozważań, gdzie jego uczciwie nieukrywana aksjologiczna prywatność pozostaje jednym z równoważnych opcjonalnych głosów w prowadzonej przezeń analizie problemowej. To urok eseju: uczynić własne poglądy współkomponentem filozoficznej agory. A uznawszy aproksymacyjną procesualność prawdy, nie trzeba bać się szczególnie $\mathrm{w}$ końcowych partiach rozważań - pytań otwartych, heurystycznych niedopowiedzeń czy werbalizacji wątpliwości, lecz afirmować sytuacje interpretacyjnej polirozstrzygalności. Być może to nie nagły skok w otchłań 'odpowiedzi ostatecznych', lecz raczej wyciszenie okaże się trafnym spuentowaniem narracji: nie Bolero, lecz np. finał IX Symfonii A. Dwořáka. Ważniejsza od samej konkluzywności jest intelektualna dramaturgia narracji i zakończenia. Tylko bowiem tekst może uwolnić piszącego z obowiązków medialnych. Zarazem jednak, dla komfortu pisania, aby uniknąć presji „ostatecznych terminów” lepiej jest aplikować o grant badawczy (tym samym o fundusze na publikację) mając już gotowe umowne $90 \%$ finalnej wersji tekstu.

I kolejna kwestia: pisanie powzięte z uprzednio założoną tezą pozostanie niepoznawcze, epistemicznie nietwórcze - szczególnie w humanistyce. Wszak rozwiązujemy problem, drążymy zagadnienie, a nie dodajemy sobie (którą to obsesyjną praktyką zainfekowana jest nauka zinstytucjonalizowana) literek przed nazwiskiem. Tekst musi heurystycznie zaskakiwać piszącego, prowadząc go przez odkrywcze zdziwienia. Pisząc trzeba być gotowym na ciągłe rekonstruowanie struktury własnych przekonań i budowanie jej od nowa. Pisanie nie jest odrabianiem zadania domowego, lecz przeżywaniem, eksploracją i burzeniem własnych naukowca stereotypowych przekonań, czego - owej pozytywnej dezintegracji dotychczasowej wiedzy - nie należy się bać. Piszący wnika w problem, niekoniecznie go rozwiązując, ale raczej pozostawiając klarownie przedstawione możliwe kierunki dalszych badań. Jeśli piszący pozostaje niezaskoczony konkluzjami jakich na nim dokonuje narracja, to znaczy że wywyższa się ponad tekst i jego medialność jest udawana, nie uczestniczy bowiem w kreacji. A forma eseju pozwala rozważać opcje, dyskutować z zastanymi poglądami, wyjść z neopozytywistycznej, tautologicznej klatki implikacyjno-linearnej narracji scjentycznej oraz posługiwać się zabiegami literackimi w obszarach szczególnie trudnych do konceptualizacji naukowej, a możliwych do przenośnego zasugerowania. Posługiwanie się analogią, peryfrazą, symbolami, przenośnią czy hiperbolą lub kubizmem okazuje się poznawczo funkcjonalne (por. koncepcję metafory eksplikatywnej J. Kmity). I to właśnie filozofia dopuszczająca inne niż naukowe, ale heurystyczne metody eksploracji Bytu pozwala na rozszerzenie spektrum poznania przez sięganie po środki wyrazu z obszarów pokrewnych nauk i sztuk. Zaś w pracach normatywnych, np. z zakresu etyki, dążenie do funkcjonalnej, bo konsensualnej abstrakcji realizuje warunek intersubiektywności (transcendentalizmu) i uogólnialności 
(universalizability) norm; przykładowo: zarówno umiarkowani zwolennicy, jak i zdecydowani przeciwnicy eutanazji zgodzą się ze ich opcje moralne mają realizować tę samą wartość: godność ludzką.

W pracy filozoficzno-naukowej szkoda czasu na zajmowanie się przyczynkami do danej tematyki. Należy 'atakować' wprost wielkie i zasadnicze problemy. Nauka musi tworzyć wielkie dzieła, a projekty badawcze wypada 'mierzyć w Nobla'. Albo najlepiej, albo wcale. Zaś podejście hermeneutyczne i interpretacyjno-progresywne do tekstów źródłowych i kanonicznych dla tematu, wyraża twórczy horyzont podjętych badań. Pisanie to także odkrywanie operacyjno-projekcyjnych możliwości języka w zakresie słowotwórstwa, frazeologii czy składni. Można pozwolić sobie, w imię klarowności wywodów, na eksperymenty gramatyczne, np. odejście od piętrzenia przeczeń w polszczyźnie i np. zamiast „nigdy nikogo tam nie było” wprowadzić logikę składni angielskiej: „,nigdy ktokolwiek tam byl”. Z kolei na etapie przygotowywania pracy (książki) do druku, czyli na etapie korekt redakcyjnych i technicznych pojawić się musi - szczególnie w opracowaniach filologicznych i historycznych - problem znaków metajęzykowych. Jeśli mamy bowiem do czynienia $\mathrm{z}$ sytuacją gdy cytujemy X-a, który np. przeprowadzał wywiad z Y-kiem, który z kolei powoływał się na to co powiedział mu Z, powtarzając wcześniejsze słowa skierowane do Z-ta jeszcze przez kogoś innego, to te wielopoziomowe supozycje muszą być klarownie oddane przez zróżnicowanie graficzne cudzysłowów odnoszących się do poszczególnych, konsekutywnych cytowań. Ważna jest na tym etapie dobra współpraca $\mathrm{z}$ wyczulonymi na tę kwestię oraz słowotwórstwo redaktorami wydawniczymi. Formalne zróżnicowanie cudzysłowów przydaje się także gdy jeden z nich pełni funkcję znaku metajęzykowego supozycji materialnej, czyli gdy przedmiotem rozważań jest sam termin/fraza ujęte w tenże cudzysłów (np. „..."), inny zaś gdy słowo/fraza w nim ujęte użyte jest literacko: przenośnie, symbolicznie, eufemistycznie, umownie, parafrazująco czy ironicznie (np. '...').

I wreszcie kwestia delikatna: nie wolno liczyć się z odbiorcą, czyli autocenzurować na zasadzie „no bo jak to zostanie przyjęte?”. Owa bezkompromisowość narracyjno-konkluzywna wymaga, już na wstępie, jasnej deklaracji merytorycznego spektrum adresatów, przy czym należy zarazem założyć kompetencje odbiorcy jako interpretatora oraz korzystać z recenzji i uwag fachowców z branży. Pisanie jest bowiem pozostawianiem swego śladu w kulturze Homo sapiens, jest wyjściem poza przemijanie, stanowi dar bycia medium wybranym przez Słowo/Tekst-Logos. W konsekwencji to piszący jest odpowiedzialny za wierność kanonom naukowości, w tym za metodologiczną poprawność warsztatową badań wyznaczonych tekstem oraz przekazu treści (pytań, dociekań, alternatywnych konkluzji), za dobór wiarygodnych źródel, rzetelność referencji, cytatów i translacji interjęzykowych, za logiczną koherencję wywodów i wnioskowań etc. Zważywszy na wymogi logicznej prostoty, komunikowalności, sprawdzalności oraz niebanalności wiedzy naukowej, wszelki 'barok' 
terminologiczno-frazeologiczny czy „interpretacyjne wygibasy”, nie mające choćby pośrednich przesłanek w oparciu o teksty źródłowe, od razu budzą podejrzenie, iż piszący nie ma czegokolwiek poznawczo cennego do powiedzenia. A nade wszystko: nie należy mnożyć bytów pojęciowych ponad potrzebę eksplanacyjną.

Czy jednak pewien - uważamy, że w humanistyce niezbywalny arystokratyzm duchowy zawarty $\mathrm{w}$ powyższej wizji jest we współczesnej praktyce naukowej realizowalny? $\mathrm{Z}$ jednej strony praktyka ta odbywa się $\mathrm{w}$ warunkach zurzędniczałej formuły akademickiej, ale zarazem humanistyka żyje tekstami, które jako takie żyją dzięki interpretacyjnemu ich traktowaniu przez odbiorców. A gdy ów odbiorca jest słabo wykształcony, nieoczytany, nieuczestniczący w wydarzeniach kultury wysokiej, umysłowo bezwolny, gdy duchowo nie jest o-sobą, wtedy także komunikacyjne społeczeństwo obywatelskie zamiera jako takie. Zważmy, iż wszelkie totalitaryzmy dążą do opanowania sfery informacyjnej oraz edukacyjnej, w celu duchowego zubożenia i zestandaryzowania odbiorców tekstów funkcjonujących w obiegu publicznym. Ta kwestia prowadzi nas ku kilku refleksjom na temat państwowego systemu edukacji w Polsce. Naszym zdaniem pełzające od kilku lat reformowanie szkolnictwa wyższego i warunków samej pracy badawczej oprócz niewątpliwych plusów (np. system grantów) ma też uciążliwe, nie sprzyjające inicjatywom naukowym minusy. Przykładowo, finansowoizolacjonistyczna samodzielność wydziałów oraz elektroniczne systemy obsługi dydaktyki hamują interdyscyplinarną kooperatywność na poziomie programów dydaktyki podstawowej $\mathrm{w}$ zakresie tzw. przedmiotów fakultatywnych. Także interdycyplinarne prace na stopnie naukowe napotykają trudności - chociażby w doborze recenzentów - ze strony formalnego układu przepisów rządzących procedurami naukowego awansu, w postaci 'szufladkowego' podziału nauki na dyscypliny i specjalności. W humanistyce ten system zupełnie się nie sprawdza. Szkolnictwo wyższe w Polsce umiera w separatyzmie dziedzin i kierunków. A to właśnie intelektualne spotkanie humanistyki i szeroko rozumianego przyrodoznawstw a stwarza perspektywę kolejnych aproksymacji wielkiego marzenia naukowców: Ogólnej Teorii Wszystkiego.

Co więcej, kolejna już ustawowa (tzw. Ustawa 2.0) reforma szkolnictwa wyższego ma w ukrytym celu zniszczenie humanistyki akademickiej, zawsze wszak będącej ostoją sumienia społecznego. Humanistyka budzi strach, gdyż demaskuje preferencyjność, w tym ideologiczno-polityczny partykularyzm i stronniczość dążeń oraz strukturalnych rozwiązań wdrażanych przez koła rządzące, a przedstawianych jako rzekomo uniwersalnie postępowe, awangardowe i pro publico bono. Preferowanie tzw. wdrożeniowych (bezhabilitacyjnych) stopni naukowych, skierowane jest przeciwko badaniom podstawowym, czyli nauce sensu stricto. Planowano także redukcję roli rektora do reprezentacyjno-marionetkowego ozdobnika, a uczelnią, która ma 
być ściśle powiązana z biznesem i polityką, zarządzać miał jej prezydentmenadżer (bez wymogu samodzielnego dorobku naukowego) wraz z tzw. radą uczelni, czyli naczelnym jej organem, reprezentującym - większościowo w swym składzie osobowym - interesy środowisk pozaakademickich, otoczenia społeczno-gospodarczego oraz resortu nauki i szkolnictwa wyższego, reprezentującego z kolei zmieniające się opcje polityczne. Rada ta miała całkowicie kontrolować proces zarządzania uczelnią przez rektora (którym mógłby być zaledwie doktor), anihilując w ten sposób autonomię akademicką, co zamieniało status uniwersytetów na de facto wyższe szkoły zawodowe, pełniące funkcje usługowe dla gospodarki. W finalnej wersji ustawy owa rada ma składać się $\mathrm{w}$ minimum połowie z osób obcych nauce, być organem doradczym i opiniodawczym wobec decyzji senatu uczelni oraz zgłaszać (równoprawnie z innymi statutowymi organami uczelni) swego kandydata na rektora. Zachowana pozostaje dywersyjna wobec środowiska stricte naukowego i społecznej praktyki naukowej rola tego nowego $\mathrm{w}$ strukturze akademickiej organu. Nastąpi zatem - tak jak w sądownictwie upolitycznione zawłaszczenie partyjne uniwersytetów. Ustawa ta służy typowemu dla taktyki faszyzmu wprowadzaniu ciał obcych - czyli swoistego aksjologicznego raka - w obręb demokratycznej samorządności ośrodków naukowych. Owa reforma - podejmująca kolejną próbę państwowego sterowania nauką, co pozostaje egzemplum powracającego w historii Homo sapiens zjawiska obłędu ideologicznego - jedynie pogłębi trwającą deelitaryzację (poprzez deintelektualizację) studiów wyższych, doktoranckich i kolejnych szczebli awansu naukowo-akademickiego oraz wygeneruje podziały środowiskowe, ułatwiając zewnętrzne sterowanie uczelniami. Zarazem ogólne zmiany ustawodawcze przewidują dla ludzi nauki wiek emerytalny 65 lat, a więc moment największej aktywności i możliwości intelektualnych w zakresie badań podstawowych. Dokona się w ten sposób zerwanie transpokoleniowej transmisji kultury wysokiej. Tylko z gruntu moralnie słabe i sfrustrowane państwo traktuje uczonych jak materiały odpadowe.

Jednakże nieszczęście humanistyki w Polsce, a szerzej ujmując: deprecjacja wyższego wykształcenia $\mathrm{w}$ ogóle, zaczyna się już na etapach szkoły podstawowej i średniej. Polskim uczniom skrycie bowiem odebrano prawo do interpretacji treści z jakimi się spotykają, interpretacji zgodnej z ich odczuwaną tożsamością egzystencjalną, kształtowaną głównie przez środowisko rodzinne i własne uczestnictwo w kulturze. Ukrytym strategicznym celem nauczania jest przeciętność i deindywidualizacja, 'wytresowanie' posłusznego, bezmyślnego, niesamodzielnego intelektualnie, bezkrytycznego adresata, latwo ulegającego pragmalingwistycznej manipulacji treściami zawartymi $\mathrm{w}$ przekazie ideologiczno-politycznym przyszłego wyborcy, budowniczego kulturowo-etnicznych murów. Służy temu model swoistego totalitaryzmu (uniformizmu, schematyzmu) dydaktycznoprogramowego i aksjologicznego szkoły jako instytucji państwowej, czyli ideologicznej, a w przypadku Polski infekującej wyznaniowym nacjonalizmem. Wszak już sofiści odkryli, że język w swej funkcji wpajania 
(imprinting), to narzędzie władzy. Obecna sytuacja Polski przypomina okoliczności upadku Republiki Weimarskiej: słaba demokracja, łatwo dająca się rozmontować neofaszystowskiej opcji politycznej. Faszyzm to wszak przede wszystkim sposób myślenia o 'porządkowaniu-oczyszczaniu' świata: zaczyna się od spalenia kilku książek, po czym przychodzi kolej na miliony ludzi. A swoiste niszczenie tekstów przez ich celowe pomijanie w procesie edukacyjnym, czyli niszczenie Popperowskiego „trzeciego świata”, to zabijanie kulturowej pamięci i tożsamości, duchowe wyjaławianie, aby móc szybko wpajać koniunkturalne światopoglądy i quasi-religie.

Faszyzacja państwa - a więc przemiana społeczeństwa w 'stado (łatwo przekupnych) marionetek' - zawsze zaczyna się od opanowania kluczowych dla konstytucyjnego ustroju instytucji władzy, następnie zmierza do fundamentalnych zmian prawnych mających legitymizować rządy, prowadząc w końcu do zainstalowania specjalnych miejsc odosobnienia dla przeciwników politycznych. Współcześnie mają to być nowego typu więzienia przeznaczone dla humanistów, niezależnych myślicieli, zwolenników neutralnej religijnie postnarodowej (nienacjonalistycznej) demokracji, pokojowych opozycjonistów różnobarwnych orientacji, obrońców przyrody (przed meblowym, myśliwskim, budowlanym, czy laboratoryjnym lobby), członków różnych sekt (np. czcicieli cebuli) etc. Czy można - wobec ewidentnych obecnie zagrożeń - liczyć na skuteczność zbiorowych protestów, skoro w swej podstawowej masie elekcyjnej społeczeństwo jest bezwolne i omamione, bo słabo wykształcone i nie myślące po obywatelsku, co generalnie pozostaje historycznym skutkiem intelektualnie i politycznie straconego okresu Oświecenia w Polsce? Obecna polityka edukacyjna (której przeciwstawić się może jakiś samoświadomy, wspólnotowo zorganizowany bunt pracowników oświaty przeciwko choremu aksjologicznie i organizacyjnie systemowi, w którym partycypują) zabija obywatelską i umysłową aktywność Polaków. Ta okoliczność wraz z wprowadzeniem (w ramach tzw. systemu Bolońskiego) dyplomu licencjackiego (zaświadczającego o niepełnym wykształceniu wyższym; przy zawodowym, a nie naukowym statusie tytułu magistra), niżem demograficznym oraz propagandową dewaloryzacją - a nawet wyszydzaniem - wykształcenia wyższego, istotnie obniża rangę społeczną intelektualistów, którzy popadają w mało szacowną autoizolację. Realizowana przez państwo strategia podważania zaufania do wiedzy stricte naukowej owocuje występowaniem w świadomości potocznej dziwacznych przekonań typu: „szczepienia powodują autyzm”. Niestety, w samym środowisku akademickim niepokojąco często zachodzą kompromitujące grzechy, które społeczną erozję owego zaufania pogłębiają, np. prace niesamodzielne, czy też dopisywanie się kierowników jednostek do autorstwa prac swoich pracowników, aby zwiększyć własny 'dorobek' publikacyjny.

W powyższym kontekście ujawnia się tragizm zawodu nauczyciela $\mathrm{w}$ Polsce: musi on realizować odgórne założenia programowe oraz dostosowywać wymagania do poziomu najsłabszych uczniów, a świat - mimo 
dydaktycznego poświęcenia uczących - nie staje się kulturalnie i intelektualnie lepszy. A współczesny faszyzm bazuje na mierności intelektualnej odbiorcy swych haseł politycznych. Tymczasem, po 1989 roku środowisko (dodajmy, iż politycznie niejednorodne i niesolidarne) nauczycieli, wszystkich zakresów polskiego systemu edukacji, nie zadbało o zbudowanie struktury społecznego szacunku dla swego profesji, która jest wszak misją, właśnie z powodu zbyt posłusznego uczestnictwa w realizacji miernych treściowo i formalnie podstaw programowych nauczania, co odbija się na narzuconej im przez państwo patologicznej moralnie relacji między płacami a obowiązkami. Poniosło w tym względzie porażkę. W konsekwencji, ich ewentualny protest $\mathrm{w}$ imię fundamentalnych aksjologicznie racji godnościowych oraz merytoryczno-dydaktycznych, a więc na rzecz kulturowej odpowiedzialności za poziom intelektualny (szerzej: duchowy) absolwentów różnego typu szkól, nie spotka się z poparciem innych grup społeczno-zawodowych, czy też masy rodziców, gdyż będzie interpretowany nie w kategoriach fundamentaliów moralnych, lecz jako konkurencja do udziału w budżetowej kasie państwa. Reanimacja etosu może być tyleż heroicznie-rozpaczliwa ( $w$ kategoriach godnościowych), co politycznie ryzykowna i przeciągła.

Zwróćmy też uwagę na działanie prawa Kopernika-Greshema: rozpowszechnia się korupcjogenna (tania) duchowa/umysłowa bylejakość, natomiast talenty albo giną w masie, albo - jeśli już rozpoznane - z trudem uzyskują możliwość separacyjnych, indywidualnych ścieżek edukacyjnorozwojowych. Jakość nauczania nastawionego na wymuszone uśrednianie musi spadać. I nie jest to tylko kwestia partykularnych (np. nacjonalistycznowyznaniowych) preferencji programowych i zamierzonej 'produkcji' bezrefleksyjnych, zdeindywidualizowanych, latwych do sterowania przeciętniaków. Zagrożenie jest bardziej fundamentalne i globalne. Nazwijmy je przenośnie: aksjologiczną entropią kultury. Mamy współcześnie do czynienia nie tyle ze wzrostem nieuporządkowania wartości w kulturze Homo sapiens, co z degradacją, symplifikacją i unifikacją ludzkich ważności w tejże kulturze; $\mathrm{z}$ - zawartym $\mathrm{w}$ pierwotnym (termodynamicznym) rozumieniu entropii - redukcjonizmem/degradacją energii, czyli $\mathrm{w}$ analizowanym tu kontekście: potencjału i dynamiki aksjosfery kultury. Jest to porządkowanie przez zubażanie i homogenizację różnorodności. Szkoła państwowa (w jej obecnym modelu!) pozostając - obok więzienia i szpitala - instytucją typu totalitarnego $\mathrm{w}$ ramach społeczeństwa nominalnie obywatelskiego, takiej właśnie uniformizacji i martwocie aksjologicznej świadomości wychowanków służy. Kult duchowej jednolitości rozprasza i zabija w umysłach uczniów nie tylko spektrum, ale i wolę szukania własnych sensów egzystencjalnych; proponując żałosnej jakości ideologiczno-religijny surogat, szkoła taka dezaktywuje ich kulturowo. W izolacjonizmie wpajanych 'oficjalnych' wartości usycha inwencja i chęć uczniów do własnych interpretacji serwowanych treści, czyli do szukania różnych życiowych perspektyw narracyjnych dla siebie. 
Destrukcyjny dla kulturowego, a w rezultacie cywilizacyjnego (np. jakości funkcjonowania prawa i instytucji państwa) poziomu społeczeństwa, pozostaje brak w szkole propedeutyki filozofii i kulturoznawstwa oraz stymulacji indywidualizmu; dominuje zaś aksjojęzykowa monotonia edukacyjno-wychowawcza i kryptoindoktrynacja światopoglądowa. Dla rozwoju humanistyki (docelowo: na najwyższym poziomie naukowym) kluczowa jest stymulacja atrybutów humanistycznej osobowości uczniów na wczesnych etapach ontogenezy. Jaką wiedzą - w tym historyczną - ci przyszli decydenci będą dysponować? Kluczowa jest praca z tekstem: aideologiczny dobór nieinfantylnych (z szacunkiem dla uczniów!) lektur, ukazanie uczącym się spektrum możliwości interpretacyjnych (w tym alegorycznych) w ich czytaniu i przyswajaniu wizji teoretycznych, zachęcanie do inicjatywności i wolności w obcowaniu z kulturą wysoką, w której cenna jest także herezja, czyli kreatywne odstępstwo od przyjętego standardu interpretacyjnego, wychodzące od wspólnych założeń i literalności tekstu. Uczeń musi wiedzieć, że dysponuje bogactwem odniesień wartości obecnych w śródziemnomorskim i innych kręgach kulturowych. Różnorodność ta to kumulacja 'aksjologicznej energii', zgromadzony przez ludzkość potencjał kulturowy, spektrum inspiracji duchowych, żywotność wielkich spierających się idei i ich działanie w sferze społecznej świadomości. W starszych klasach jest już pora na krytyczne czytanie - z pomocą fachowego nauczyciela kanonicznych dla Europejczyków tekstów Biblii i Koranu. Rozbudza się wtedy potrzeba bezpośredniej rozmowy $\mathrm{z}$ sacrum, bez zinstytucjonalizowanych pośredników. Różnorodność jest nieredukowalnym status-quo Bytu, w tym aksjosfery kultury jako teleonomicznej (adaptacyjnie funkcjonalnej) niszy ekologicznej Homo sapiens w biosferze. Zauważmy, iż w mitologii chrześcijaństwa (tu: przypowieść o wieży Babel, będąca mitem założycielskim etyki komunikacji) Bóg pomieszał ludziom języki, chroniąc ich właśnie przed monotonicznością myślenia i mówienia, inicjując konieczność dyskursu AJOS-ów, gdyż wszelkie aksjologiczne mono prowadzi do totalitaryzmu. A priorytet edukacyjny na rzecz rozwoju humanistyki - a więc promocji różnic przeżywania treści lektur i zadań szkolnych, wraz ze zróżnicowaniem narracji przekazu tegoż przeżywania - stanowiłby prewencję duchowego (aksjologicznego) uwiądu człowieka.

W zuniformizowanym świecie, zdominowanym przez anglo-amerykański model życia i porozumiewania się, giną języki, a więc aksjoobrazy rzeczywistości doświadczanej. Albowiem znika świat małych ojczyzn, w którym miały one swe odniesienia i odchodzą ludzie, którzy danymi językami mówili, a w konsekwencji zanikają umiejętności społeczno-komunikacyjne z nimi związane, a szerzej: sposoby na życie i międzygrupowa wymiana doświadczeń egzystencjalnych oraz wizji świata. Dotyczy to zarówno języków etnicznych jak i stanu poliglosji, czyli wielości sposobów wyrażania i transmisji ważności w ramach danego języka naturalnego. Zamiera transpokoleniowa transmisja AJOS-ów, ubożeje kultura Homo sapiens, bo następuje w niej degradacja energii=różnorodności aksjologicznej. Coraz mniej jest heurystycznych poznawczo interpretacji ewolucyjnej kondycji 
Homo sapiens na Ziemi, czyli coraz mniej pomysłów na funkcjonowanie ludzkości nie jako raka biosfery. Ostają się najprostsze formy świadomości społecznej: szowinizmy/nacjonalizmy, totalitaryzmy, czarno-białe schematy widzenia uniwersum interakcji i procesów społecznych, muzyka techno, komputerowe gry wielokrotnej śmierci i religie plebejskich sportów. Kultura to wszak także sposób zagospodarowania wolnego czasu, co świetnie ilustrują naskalne malowidła człowieka z Cro-Magnon.

A co współczesna młodzież ma sobie do zaproponowania? Czy może czytanie ze zrozumieniem i polemicznym uczestnictwem w wielkich tekstach, w ideowych narracjach własnej kultury? Pokolenie czasów obrazkowokomputerowego getta boi się tekstowej formy przekazu treści, gdyż pozostaje wobec niej intelektualnie=szkolnie bezradne. Dziś niestety jest normą, iż młodzież dopiero na pierwszym roku studiów dowiaduje się, co to Akropol i Partenon (sic!), a po semestrze wykładów z filozofii wciąż kojarzy metaforę „przewrotu kopernikańskiego” z astronomią. Platon - duchowy ojciec europejskich totalitaryzmów - wyrzucił ze swego idealnego państwa poetów i artystów, jako ludzi zbyt wolnych intelektualnie. Dziś ludzi pióra, sztuki czy nawet nauczycieli można po postu zagłodzić odbierając im - w ramach systemowej strategii powszechnego niedokształcania - kompetentnych odbiorców ich przekazu. Ratunkowym nakazem chwili - w obliczu aktywności resentymentów i przeróżnej maści ekstremizmów, ale także bezosobowej (neoliberalnej) wizji świata - wydaje się wychowanie i edukacja w duchu personalizmu humanistycznego, na rzecz tolerancyjnego i komunikacyjnie konstruktywnego współuczestnictwa w kulturze.

Nauka przestała być w Polsce twórczością ergo heurystyczną herezją intelektualną, a stacza się w przepaść 'Wielkiej Smuty Akademickiej', opętanej obsesją punktacji, list rankingowych, algorytmów akredytacji/ewaluacji, planów i 'strategii' publikacyjnych, ilości cytowań, hipersprawozdawczości, formalnym separatyzmem dyscyplin i kultem obiegu urzędowych pism wewnętrznych. Drastycznie zaniżono także wymagania jakie musi spełniać monografia naukowa, ów swoisty 'okręt flagowy' w naukowym CV. Co gorsza, w rzekomą epistemiczną rolę tych wdrukowanych w świadomość nauczycieli akademickich pozamerytorycznych procedur produkcyjno-statystycznych, zaczynamy już wierzyć, nie dostrzegając swego pokornego uczestnictwa w narastającej paranoi. Einstein, Skłodowska czy Kopernik zginęliby dziś w tym molochu, lub...wyemigrowali. Pilnie trzeba się ocknąć i rehumanizować życie akademickie, czyli wyzwalać - powracając do istoty aktywności naukowej, która nie jest fabryczną produkcją - indywidualną kreatywność teoretyczną (eksplanacyjno-interpretacyjną) i intelektualny nonkonformizm. Nauce potrzeba specyficznych osobowości (tu: tzw. 'ludzi bez właściwości', czyli nie przywiązujących się do ustalonych teorii i zdolnych do tzw. intelektualnej dezintegracji pozytywnej) oraz stworzenia im warunków katalizujących wyzwolenie talentów twórczych. Nauka, albo pozostaje swobodną twórczością, albo jej niema. Obecna zapaść edukacyjna pogłębia 
anachroniczność potocznej świadomości Polaków, którzy myślą wąsko i wsobnie (czym nie różnią się mentalnie od np. Rosjan), ale tym samym nie uczestniczą w wielkich przemianach cywilizacyjnych i ideowych (aksjologicznych) współczesnego świata, gdyż nie rozumieją jego humanistycznej złożoności i dynamiki, czyli makrokulturowej gry wielości równoprawnych narracji; masochistycznie zakochani we własnych historycznych klęskach i przekłamanej wielkości, permanentnie użalający się nad rzekomym niedocenieniem przez Europę, nie dostrzegają swej aksjologicznej autoizolacji, a stąd cywilizacyjnej degradacji. To właśnie humanistyka musi inicjować nowe narracje, idee, aksjojęzykowe obrazy świata., czyli ratować otwartość duchową, a stąd żywotność kulturową, w awangardzie której jawią się dziś w intelektualnej hemisferze atlantyckiej wizje postpaństwowości, postnarodowości oraz kultura komunikacyjnotranscedentalnego indywidualizmu (zainicjowana postsokratejską myślą Arystypa z Cyreny), a szerzej: personalizmu humanistycznego. Teraźniejsza misja akademizmu to: program rozwoju humanistyki zintegrowanej na rzecz intelektualnego wielogłosu twórczych kontrowersyjności.

Parafrazując ustalenia literaturoznawcze (vide prace R. Nycza): świat ukazywany w nauce, filozofii czy sztuce jest w istocie (inter)tekstowy. A humanistyczne wychowanie i edukacja powinno kształtować umiejętności odczytywania różnych ludzi, rozumienia ich narracji (tu: sposobów opowiadania o sobie i innych oraz przekazu AJOS-ów) świata, co nie znaczy zgadzania się $\mathrm{z}$ ich poglądami. Tolerancja nie polega na egalitarnej, nieselektywnej akceptacji wszystkiego (jak proponuje neoliberalizm, popadający w aksjologiczny indyferentyzm), lecz na nieniszczeniu tego co nam się nie podoba, a to w imię zachowania puli różnorodności kulturowej, której sami jesteśmy współkomponentami. Ów moralny metapoziom tolerancji zawiera w sobie postawę szacunku i życzliwego, kulturotwórczego zaciekawienia innością: oto moja prawda, powiedz mi swoją, rozmawiajmy, poszukajmy funkcjonalnej dla koegzystencji, intersubiektywnej (transcendentalnej; tu: Arystotelesowskiej formy) abstrakcji normatywnej. Można się spotkać i odnaleźć we wspólności aksjologicznej, realizowanej na różne i nieagresywne sposoby. To właśnie interpretacje, czyli wersje rozumienia tego co percypowane, wytwarzają wielodialogową, kulturową wspólnotę po-rozumienia na metapoziomie tolerancji. Wspólnota ta stanowi spotkanie narracji przedstawiających, czyli sposobów rozumienia świata, historii i własnej tożsamości, będące propozycją współkomponowania kultury w formie dyskursywnej struktury AJOS-ów, czyli koegzystencji tego co przedstawiane. W tym spotkaniu dokonuje się swoiste katharsis, uwolnienie od strachu przed porównaniami i pytaniami o siebie, od masek i kłamstw o sobie, od narracji tożsamości negatywnej (,inni są gorsi, gdyż sa inni”), czyli w istocie od kompleksu cywilizacyjnej niższości. Jest to bowiem zaklęta w język transmisja własnego doświadczenia egzystencjalnego, które okazuje swą uniwersalność (transcendentalność), gdy znajduje zrozumienie u innych. Jak mówi poeta (E. Bryll): „Bo tyle w nas jest siebie ile ciepła tego, które weźmiemy od kogoś drugiego, a drugi od nas weźmie i w sobie zatai”. 
Wyrażając tę myśl przez metaforę baletową: każdy $\mathrm{z}$ dobrowolnych uczestników kulturowego dialogu jest zarazem białym, jak i czarnym łabędziem. Zauważmy też, iż już samo dialogowanie o funkcjach dialogu konstytuuje porozumiewanie się, czyli praktykę osiągania po-rozumienia, natomiast brak możliwości dialogowania skutkuje utratą tożsamości, a już w konotacji „obcowania” zawarte jest aksjojęzykowe nizanie meta-wspólnoty tolerancji. To w metajęzyku po-rozumienia, a nie konfrontacji, tworzymy też teksty protokołów nieagresywnych odmienności, tworzymy moralne piękno zróżnicowania aksjosfery kultury ludzkiej. Na tymże poziomie kreatywnej komunikacji vita contemplativa zaczyna funkcjonować w trybie vita activa, następuje bowiem kulturotwórcza wymiana stronniczych, czyli aksjologicznie nacechowanych obserwacji świata.

Zarazem pamiętajmy, iż narracja przedstawiająca (vide koncepcje $\mathrm{H}$. White'a oraz F. Ankersmita) zawiera komponent pragmalingwistyczny o zamierzonych lub nie - perlokucyjnych skutkach, gdyż na ogół rozgrywa się w interakcyjnych warunkach dyskursu społecznego. Zarówno gra jak i konsensus tekstów pozostają intencyjne i komunikacyjne. Stąd granicą tolerowania, a więc początkiem społecznego sprzeciwu staje się sytuacja, gdy jeden ze składników (np. jakakolwiek opcja ideologiczna) kulturowej struktury różnorodności chce ją całkowicie wypełnić sobą, uznając się za nadrzędną lub jedyną prawdę, czyli gdy dąży do zniszczenia status-quo aksjologicznej homeostazy koegzystencji różnych (naukowych, filozoficznych, religijnych, światopoglądowych, artystycznych, literackich, gospodarczych, prawnych, politycznych etc) źródeł i toposów duchowego dorobku ludzkości; przykładowo: gdy językowo-kulturowa etnicznośćtradycyjność zostaje zamieniona na zinstytucjonalizowaną narodowość, a następnie na upolityczniony, dekretalnie uświęcony nacjonalizm. A właśnie na nacjonalistyczno-historycznych resentymentach zbiorowości, jej poczuciu niższości i edukacyjnym zaniechaniu oraz na obywatelskim strachu bazuje faszyzm, któremu jednakże przeciwstawić się jest $\mathrm{w}$ stanie i musi humanistyka (może jednak bez utopijnych udziwnień tzw. transhumanizmu technologicznego) personalizmu, będąca w istocie etyką kulturowego wzbogacania (culture enrichment ethics) człowieczeństwa, dla której ideałem pozostaje społeczeństwo otwarte, a więc aksjologiczny ‘ekoton’, gdzie wszyscy się spotykają na transpokoleniowej biesiadzie przeróżnych - lecz zawsze konstruktywnych - racji, gdzie panuje konsensus co do pojmowania zła jako krzywdzenia, zazwyczaj zakorzenionego w egoistycznym braku szacunku (w połączeniu z głupotą) dla innych istot żywych. Etyka ta nie pozwala rozstrzeliwać marzeń o świecie pustych więzień, bezpiecznych ulic i pełnych teatrów, postulując działania na rzecz duchowej różnorodności, rozumianej zwrotnie właśnie jako metadobro edukacyjne. Europie potrzebny jest nowy typ wspólnotowości zanim jej obecne aksjologiczne pustkowie 'zagospodaruje' faszystowsko-populistyczna narracja, i to jako zakładniczka terroryzmu. W tej perspektywie, także przyszłość samej polskości jawi się jako struktura obywatelska: polietniczna, polireligijna, wieloświatopoglądowa, i humanistyczna, czyli rozwijająca się intertekstowo. 
Rozwój ten dokonuje się $\mathrm{w}$ osnowie uniwersalnego, fundamentalnego sprzężenia kulturotwórczego: różnicowania i scalania odniesień aksjologicznych w dziejach ludzkości, czyli w formie dialektyki Jedność $\leftrightarrow$ Wielość. 


\section{Bibliografia}

Ankersmit, F., 2005, Narracja - Reprezentacja - Doświadczenie. Studia z teorï historiografii, Domańska, E., (red.) Kraków: Universitas.

Austin, J., 1993, Mówienie i poznawanie, Warszawa: PWN.

Awdiejew, A., Habrajska, G., 2006, Wprowadzenie do gramatyki komunikacyjnej (T. 2), Łask: LEKSEM.

Bartmiński, J., 2006, Językowe podstawy obrazu świata, Lublin: Wydawnictwo UMCS.

Buczyńska-Garewicz, H., 2003, Milczenie i mowa filozofii, Warszawa: IFiS PAN.

Domańska, E., 2012, Historia egzystencjalna. Krytyczne studium narratywizmu $i$ humanistyki zaangażowanej, Warszawa:PWN.

Filozofia i etyka interpretacji, 2007, Kola, A.F., Szahaj, A., (red.), Kraków: Universitas.

Habermas, J., 1999, Teoria działania komunikacyjnego (T. I), Warszawa: PWN.

Heidegger, M., 1977, List o „humanizmie”, w: Budować - Mieszkać - Myśleć. Eseje wybrane, Warszawa: Czytelnik.

Heidegger, M., 1994, Bycie i Czas (§§ 34-36), Warszawa: PWN.

Heidegger, M., 2013, W drodze do języka, Kraków: Aletheia.

Kmita, J., 1967, Wyjaśnianie naukowe a metafora, w: Studia Filozoficzne (nr 3/50).

Kmita, J., 1985, Kultura i poznanie, Warszawa: PWN.

Kmita, J, 1987, Metafora filozoficzna, w: Wokół teorii krytycznej Jürgena Habermasa, Kaniowski, A.M., Szahaj, A. (red.), Warszawa: Kolegium Otryckie.

Kmita, J., 1998, Jak stowa łączą się ze światem, Poznań: Wydawnictwo Naukowe IF UAM.

Kołakowski, L., 1972, Obecność mitu, Paryż: Instytut Literacki.

Nycz, 1990, Intertekstualność i jej zakresy, w: Pamiętnik Literacki (nr LXXXI, z. 2).

Nycz, R., 1993, Tekstowy świat. Poststrukturalizm a wiedza o literaturze, Warszawa: IBL PAN.

Nycz, R., 2013, W stronę humanistyki innowacyjnej: tekst jako laboratorium. Tradycje, hipotezy, propozycje, w: Teksty Drugie (nr 1-2).

Pałubicka, A., 2006, Myślenie w perspektywie poręczności a pojęciowa konstrukcja świata, Bydgoszcz: OW Epigram.

Pałubicka, A., 2013, Gramatyka kultury europejskiej, Bydgoszcz: OW Epigram.

Ricoueur, P., 2003, O sobie samym jako innym, Warszawa: PWN.

Searle, J., 1987, Czynności mowy, Warszawa: IW Pax. 
Trzebiński, J., 2001, Narracja jako sposób rozumienia świata, w: Praktyki opowiadania, Owczarek, B., Mitosek, Z., Grajewski, W., (red.), Kraków: Universitas.

Wawrzyniak, J., 2000, Teoretyczne podstawy neonaturalistycznej bioetyki środowiskowej, Poznań: Wydawnictwo Naukowe IF UAM .

Wawrzyniak, J., 2005, Aksjologiczność $i$ etyczność nauk społecznych, w: Etyczne aspekty badań społecznych (Człowiek i społeczeństwo, t. XXIV), Zamiara, K., (red.), Poznań: Wydawnictwo Naukowe UAM.

Wawrzyniak, J., 2015, Etyka eutanazji. Studium filozoficzno-aksjolingwistyczne, Poznań: Wydawnictwo Naukowe UAM.

White, H., 2009, Proza historyczna, Domańska, E., (red.), Kraków: Universitas.

White, H., 2010, Poetyka pisarstwa historycznego, Domańska, E., Wilczyński, M., (red.), Kraków: Universitas .

White, H., 2014, Przeszłość praktyczna, Domańska, E., (red.), Kraków: Universitas.

Zeidler, P., 2011, Wiedzotwórcza funkcja metafor w nauce a koncepcja metafory eksplikatywnej Jerzego Kmity, w: FILO-SOFIJA (nr 12/2011/1), Bydgoszcz: PTF i BTN. 